\title{
The influence of the irrigant QMix on the push-out bond strength of a bioceramic endodontic sealer
}

\section{Purpose}

The aim of this study was to evaluate the effect of a commercially available irrigant, the Qmix 2 in 1, on the push out bond strength of Endosequence BC which is a bioceramic based root canal sealer.

\section{Material and methods}

Sixty extracted maxillary central incisors were prepared with Protaper Next rotary instrument up to X4 (\# 40). The specimens were randomly divided into four groups of equal sample size $(n=15)$, according to the final irrigation regimen as follows: Group 1: $2.5 \%$ sodium hypochloride ( $\mathrm{NaOCl}$ ) (control), Group 2:17\% ethylenediaminetetraacetic acid (EDTA), Group 3: 2\% Chlorhexidine (CHX), Group 4: QMix 2 in 1. After rinsing, teeth were obturated using gutta-percha with Endosequence BC sealer. Slices were obtained from coronal, middle, and an apical section of the root canal. Push-out test was performed to evaluate the bond strength between the root canal dentin and the sealer. Data was statistically analyzed.

\section{Results}

The push-out bond strength of the root canal sealer was significantly affected by the type of irrigation solution. Highest bond strengths were found in canals irrigated with Qmix solution, and these results were regardless of anatomical section of the root canal $(p<0.05)$.

\section{Conclusion}

Final irrigation of the root canals with QMix had a positive effect on the bond strength of Endosequence BC sealer throughout the root canal.

Keywords: Endosequence BC sealer; irrigant; push-out test; Qmix; endodontics

\section{Introduction}

The main aim of endodontic treatment is to eliminate micro-organisms from the root canal system and inhibit reinfection (1). Mechanical instrumentation is definitely one of the important factors in reducing the bacterial load of the infected root canals (1), although it is not completely effective in removing all bacteria and debris (1). Ability of instrumentation alone to debride and clean the canal is limited (2-5). Peters et al. $(2,3)$ reported that large areas of the root canal walls could remain untouched, regardless of the instrumentation technique. Accurate instrumentation and debridement of root canals is often very complicated and difficult because of their anatomical characteristics. Most of them demonstrate oval morphology in shape and include the lateral canals, isthmuses, and deltas $(2,3)$. Rödig et al. (4) showed that debridement with the nickel-titanium (Ni-Ti) rotary instruments of buccal and lingual extensions of oval canals may still be inadequate. Similarly, Wu and Wesselink (5) reported that uninstrumented areas may be left in many oval canals after the instrumentation. Therefore,

\author{
Mustafa Gündoğar ${ }^{1}$, \\ Güzide Pelin Sezgin², \\ Erhan Erkan', \\ Özgün Yusuf Özyılmaz ${ }^{3}$
}

ORCID IDs of the authors: M.G. 0000-0001-8656-7101; G.P.S. 0000-0002-1786-1929; E.E. 0000-0003-2631-3286; Ö.Y.Ö. 0000-0003-4802-1604

'Department of Endodontics, Medipol University Faculty of Dentistry, Istanbul, Turkey

${ }^{2}$ Department of Endodontics, Biruni University Faculty of Dentistry, istanbul, Turkey

${ }^{3}$ Department of Prosthodontics, Medipol University Faculty of Dentistry, istanbul, Turkey

Corresponding Author: Güzide Pelin Sezgin E-mail: psezgin@biruni.edu.tr

Received: 24 January 2017 Revised: 10 March 2017 Accepted: 5 April 2017

DOI: $10.26650 /$ eor.2018.446 
irrigation of root canals is the only way left to eliminate microorganisms and debris from the root canal walls, which could not be reached by mechanical instrumentation.

Sodium hypochlorite $(\mathrm{NaOCl})$ solutions in concentrations ranging from $0.5 \%$ to $6.15 \%$ have been used as endodontic irrigants for more than 70 years, and they are still the most commonly used solutions for this purpose (5). Sodium hypochlorite solution has bactericidal and virucidal properties and it dissolves necrotic tissue (6). Moreover, $\mathrm{NaOCI}$ has a low viscosity and long shelf life (6). On the other hand, this solution may be toxic and cannot break up inorganic contents of the smear layer (7). Because of this, $\mathrm{NaOCI}$ has been used with chelating agents like ethylenediaminetetraacetic acid (EDTA) in $15-17 \%$ concentrations for smear layer removal. Combined used of these irrigants represents the current optimal irrigation protocol. However, $\mathrm{NaOCl}$ and EDTA should not be combined in situ, because EDTA strongly reduces free chlorine in $\mathrm{NaOCl}$ solutions, mostly rendering them ineffective $(8,9)$. Furthermore, it has been shown that using $\mathrm{NaOCl}$ as a final irrigant after the use of EDTA may compromise the structural integrity of the dentin $(8,9)$. Chlorhexidine ( $\mathrm{CHX})$ solution in $2 \%$ concentration is also a widely used root canal irrigation solution. It has long term antimicrobial effect, comparatively low toxicity (7). However, when $\mathrm{CHX}$ comes in contact with residual $\mathrm{NaOCl}$, subsequent chemical reaction produces para-chloroaniline precipitate which is potentially toxic (10). Thus, it requires to remove any remaining $\mathrm{NaOCl}$ solution from the root canal with saline, alcohol or distilled water prior to $\mathrm{CHX}$ application (10).

To overcome these problems in the irrigation of the root canals, a new irrigation solution, QMix 2in1 (Dentsply Tulsa Dental, Tulsa, OK), has been introduced to market for smear layer removal with antimicrobial efficiency. It comprises of EDTA, $\mathrm{CHX}$, a detergent and deionized water. It is designed as a final irrigant to replace $17 \%$ EDTA final wash protocol, and is used for $60-90$ seconds (11). QMix is a ready-to-use clear solution, and requires no chair-side mixing. It has been shown that QMix 2in1 is effective in both removing the smear layer and killing bacteria such as Enterococcus faecalis in one application (11). Elnaghy (12) reported that QMix 2 in 1 could remove the smear layer more effectively than 17\% EDTA and 17\% EDTA/2\% CHX based on the completely opened dentinal tubules. Eliot et al. (13) have also stated that QMix removed more smear layer than EDTA. Furthermore, QMix eliminates some disadvantages of both EDTA and CHX. It does not interact with residual $\mathrm{NaOCl}$ if used for the purpose of final irrigation (14).

Using gutta-percha with various types of sealers is the standard technique in endodontic obturations. Tricalcium silicate based Endosequence BC Sealer (Pulpdent, Watertown, Massachusetts USA) has recently been used to treat root canals. It is an aluminum-free material comprised of calcium, calcium phosphate, zirconium oxide and calcium hydroxide that requires the existence of water to harden. It shows alkaline $\mathrm{pH}$, antibacterial activity, radio-opacity and biocompatibility (15).

The use of irrigants before the obturation of root canals is very important to dissolve organic and inorganic contents of the smear layer, to clean the dentin walls and enhance the bonding of root canal sealers. The data regarding the effects of QMix irrigation solution on the bond strength of root canal sealers is limited. Therefore, the aim of the present study was to assesment the effect of QMix irrigant on the push out bond strength of a bioceramic endodontic sealer. The main null hypothesis tested in the present study is that the push-out bond strength of Endosequence $B C$ sealer in root canals irrigated with Qmix is not different from those irrigated with $\mathrm{NaOCL}$, EDTA and CHX.

\section{Materials and methods}

\section{Specimen selection}

This in vitro study was conducted on 60 maxillary central incisors extracted within 6 months prior to the experiments and stored in $0.1 \%$ thymol solution at $4^{\circ} \mathrm{C}$. The inclusion criteria were straight canals and completely formed apices. The exclusion criteria were teeth with root caries, cracks, resorption, incomplete apices, or those with root length less than $15 \mathrm{~mm}$. This study was confirmed by the Research Ethics Committee of Medipol University (project no: 324).

\section{Specimen preparation}

The specimens were stored in $1 \%$ Chloramine $\mathrm{T}$ solution (Ricca Chemical Company, Arlington, TX) for 48 hours for disinfection. Then, the external root surfaces were scaled with ultrasonic instruments, and rinsed with distilled water for the elimination of remnants from the root surface. The crowns were sectioned transversally at the cementoenamel junction. and the root length was set to $15 \mathrm{~mm}$, and later access cavity was established, the working length was detectioned by a direct method of withdrawing $1 \mathrm{~mm}$ from the real root length. Root canals shaping were done with Protaper Next (Dentsply / Maillefer, Ballaigues, Switzerland) up to X4 (\#40) master apical file size. During the shaping, the root canal was irrigated by $2 \mathrm{~mL} 2.5 \% \mathrm{NaOCl}$ (ImidentMed, Konya, Turkey) solution after preparation with each file. The roots were then randomly divided into four groups $(n=15)$ according to the final irrigation ptotocol as follows: Group 1: $5 \mathrm{~mL}$ of $2.5 \% \mathrm{NaOCl}$ for 60 seconds (control), Group 2: $5 \mathrm{~mL}$ of $17 \%$ EDTA solution (Pulpdent, Watertown, Massachusetts USA) for 60 seconds, Group 3: $5 \mathrm{~mL}$ of $2 \% \mathrm{CHX}$ (Consepsis, Ultradent, South Jordan, UT) for 60 seconds (washed with distilled water before $\mathrm{CHX}$ application), Group 4: $5 \mathrm{~mL}$ QMix 2in 1 (Dentsply Tulsa Dental, Tulsa, OK) for 60 second.

Root canals irrigated with a 30-g side-perforated irrigation probe (Canal Clean, Biodent Co. Ltd, South Korea) and a syringe. Final rinsing was done for one minute in each canal. At the procedure of irrigation, the needle was used with up and down movements in the canal to within 1-2 mm of the working length. Subsequent to the procedures, all the canals were dried using paper points and obturated with Endosequence BC sealer (Brasseler USA, Savannah, GA) using the single cone technique with matching taper $\mathrm{X} 4$ gutta-percha cones (Dentsply Maillefer, Ballaigues, Switzerland) to achieve standard samples for push-out test. After root obturation, the coronal accesses of the root canals were sealed with temporary filling material. Teeth were stored at $37^{\circ} \mathrm{C}$ and $100 \%$ relative humidity for seven days to allow the sealer to set. 


\section{Push-out bond strength}

Each samples was horizontally cut with a low-speed diamond. saw (Isomet, Buehler, Lake Bluff, IL, USA) under cold water irrigation. Three slices in $2 \pm 0.1 \mathrm{~mm}$ thickness were obtained from the coronal, middle, and apical sections of the roots. Apical and coronal aspects of each slice were examined under a stereomicroscope (Imaging Systems, Leica Ltd., Cambridge, England) to measure the diameter of each hole.

Push-out bonding strength was calculated with a universal testing machine (TSTM02500, Elista Inc., Konya, Turkey) at a crosshead speed of $1 \mathrm{~mm} / \mathrm{min}$. As for the tapered design of the root canal, three different sizes of cylindrical pins were used for the push-out test. The diameter. of the cylindrical pins was $1.2 \mathrm{~mm}$ for the coronal slices, $1.0 \mathrm{~mm}$ for the middle slices, and $0.8 \mathrm{~mm}$ for the apical slices to make sure that the strength was implemented as adequately as possible to the adhesion area during the loading phase. The highest load implemented to the obturation material before debonding was recorded in Newton (N). The bond strength was calculated in Mega Pascals (MPa) by dividing the load $(\mathrm{N})$ by the adhesion area of root filling $(\mathrm{A})\left(\mathrm{mm}^{2}\right)$, with the equation: $\mathrm{Mpa}=\mathrm{F} / \mathrm{A}$. The parameter A was calculated with this equation: $A=\pi(R+r) \times g$, where $R$ is the coronal radius, $r$ is the apical radius, and $g$ is the height relative to the tapered inverted cone $(\mathrm{mm})$. The parameter $\mathrm{g}$ was calculated with this equation: $g^{2}=(R-r)^{2}+(2.0)^{2}$.

\section{Statistical analysis}

Statistical Package for Social Sciences SPSS version 21.0 (IBM-SPSS Inc, Armonk, NY, USA) software was used for statistical analysis. Data was first examined by use of the Shapiro-Wilk test to verify the assumption of normality and with Levene's test to check for variance equality. As the data was found to be normally distributed, one-way analysis of variance (ANOVA) test for multiple groups and Tukey HSD test for pairwise comparisons were performed. Confidence limit was regulate to $95 \%$ and $p$ values less than 0.05 were planned as statistically important.

\section{Results}

The effects of the type of irrigant on the push-out bond strength of the root canal sealer are summarized in Table 1.

Table 1. Mean and standard deviations (SD) of push-out bond strength values of study groups in Megapascal

\begin{tabular}{lcccc} 
& $\mathbf{n}$ & Mean \pm SD & Minimum & Maximum \\
$\mathrm{NaOCl}$ & 45 & $1.18 \pm 0.59 \mathrm{~A}$ & 0.23 & 2.36 \\
$\mathrm{CHX}$ & 45 & $2 \pm 0.56 \mathrm{~B}$ & 0.58 & 2.95 \\
$\mathrm{EDTA}$ & 45 & $2.51 \pm 0.42 \mathrm{C}$ & 1.76 & 3.45 \\
\hline QMix & 45 & $3.49 \pm 0.61 \mathrm{D}$ & 2.45 & 4.75 \\
\hline
\end{tabular}

CHX: chlorhexidine; EDTA: ethylenediamine tetra acetic acid; $\mathrm{NaOCl}$ : sodium hypochlorite

Different uppercase letters in columns show statistically significant differences at $p<0.05$ level
There was a significant difference between the push out bond strengths of Endosequence $B C$ sealer with respect to type the irrigation solution $(p<0.05)$. Endosequence $B C$ sealer showed the highest bond strength values when QMix 2in1 was used as the final irrigant $(p<0.05)$. On the other hand, Endosequence $B C$ sealer showed the lowest bond strength values when $\mathrm{NaOCl}$ was used as the final irrigation solution $(p<0.05)$. These results were regardless of anatomical section of the root canal $(p<0.05)$.

\section{Discussion}

Adhesion capability is a crucial factor for root canal sealers. An ideal endodontic sealer must bond to both the gutta percha and root dentin surface and must seal the root canal space (16). The effects of different irrigation solutions on the bond strength of resin based sealers to dentin have earlier been investigated (15-19). However, there is no comparative data regarding the effects of Qmix and other irrigants on the push out bond strength of a bioceramic based endodontic sealer. In the present study, we used Endosequence BC as a root canal sealer to test the effects of different irrigation solutions on its bond strength to the dentin surfaces.

The smear layer may negatively affect the bond strength of root canal sealers by acting as a barrier. As it also contains organic and inorganic contents, it should be effectively removed by different irrigation solutions (16). Studies have shown that, removing the smear layer makes it easier for the canal sealer to penetrate dentin tubules (20-23). EDTA and $\mathrm{Na}-$ $\mathrm{OCl}$ solutions are commonly used to remove the smear layer from the root canals (24). Because of its residual antimicrobial activity, $\mathrm{CHX}$ has been proposed as a supplemental final irrigation procedure after smear layer removal (25). However, the concomitant use of $\mathrm{CHX}$ and $\mathrm{NaOCl}$ leads to color changes and formation of a possibly toxic, insoluble precipitate which reduces the sealing ability of the root canal filling procedure. Also, this precipitate involves a substantial amount of parachloroaniline, which has been shown to be carcinogenic and toxic $(14,24,25)$. This substance acts as a chemical smear layer by coating the dentin surface and by changing permeability of dentin surface (26). Moreover, the mixture of $\mathrm{CHX}$ and EDTA was found to form a white precipitate which has a chemical structure of salt. This precipitate may also cover the dentin surface and alter dentin permeability. The chemical pattern of QMix prevents this, when $\mathrm{CHX}$ is combined with EDTA or $\mathrm{NaOCl}$.

Previous research concerning the smear layer elimination efficacy of EDTA and Qmix revealed contradictional results $(11,12,18,27-29)$. Some studies reported that QMix could eliminate the smear layer as effectively as 17\% EDTA (2729), while others concluded that QMix was better than $17 \%$ EDTA $(12,13)$. QMix solution is composed of EDTA, CHX and a detergent. It not only penetrates and removes the smear layer in the dentin surface but also kills bacteria within the tubules. Tuncer (18) reported that the percentage of bond strength of sealer was importantly greater in the EDTA + $\mathrm{CHX}$ and QMix groups than the $\mathrm{NaOCl}$ group. On the other hand, author stated that there was no difference between the efficiency of QMix and EDTA + CHX irrigation for smear 
layer elimination. Shokouhinejad et al.(30) showed that the existence of smear layer did not substantially affect the bond strength of obturation materials. In the present study, Endosequence $B C$ indicated the highest bond strength in root canals irrigated with Qmix. This may be the result of more efficient elimination of the smear layer by the QMix when used as a final irrigant.

Different irrigation solutions may alter the permeability and solubility of the dentin surface and therefore influence the adhesion of root canal sealers to dentin surfaces (22). Adhesion process mainly depends on the wettability of the rigid surface which is provided by the internal dentin wetness as a result of water in dentinal tubules (31). Ballal et al. (24) indicated that the wettability of the root canal dentin which is filled with AH Plus sealer is higher in canals treated with Qmix compared to those flushed with EDTA, when both solutions are used as final irrigants. This may be owing to the combined reaction of $\mathrm{CHX}$ and the detergent existence in QMix. In addition, Uzunoglu et al.(32) showed that bond strength of $\mathrm{AH}$ Plus sealer to root canal dentin is improved with QMix. However, Aranda Garcia et al. (27) stated that the surfactant compound in Qmix did not increase the bond strength of AH Plus compared to 17\% EDTA. Carvalho et al.(33) indicated that EDTA did not influence the push-out bond strength of MTA Fillapex and AH Plus. In the present study, various irrigants affected the bond strength of Endosequence $B C$ to the root canal wall differently. Endosequence $B C$ showed higher bond strength after irrigation with QMix than with EDTA and CHX.

\section{Conclusion}

Within the limitations of this in vitro study, our findings suggest that using QMix may lead to superior retention of Endosequence $\mathrm{BC}$ sealer when compared to EDTA and $\mathrm{CHX}$. From clinical perspective, Qmix solution can be used for removing the smear layer and may be considered as an alternative to using EDTA following $\mathrm{NaOCl}$ as final irrigant.

Ethics Committee Approval: Ethics committee approval was received for this study from the ethics committee of Medipol University (project no: 324, date: 15.09.2017).

Informed Consent: This study was performed in vitro by exploiting exracted teeth. Therefore written and verbal informed consent was not obtained.

Peer-review: Externally peer-reviewed.

Author Contributions: MG, GPS, EE and ÖYÖ designed the study. MG generated the data. MG and GPS gathered the data. MG, EE and ÖYÖ analyzed the data. GPS wrote the majority of the original draft. MG and GPS participated in writing the paper. All authors approved the final version of the paper.

Conflict of Interest: The authors have no conflicts of interest to declare.

Financial Disclosure: The authors declared that this study has received no financial support.
Türkçe öz: Qmix irriganının Bioseramik esaslı kök kanal patının dentine bağlanma dayanımı üzerindeki etkisi. Amaç: Bu çalışmanın amacı Qmix irriganının bioseramik esaslı kök kanal patı Endosequence $B C^{\prime}$ nin dentine bağlanma dayanımı üzerine etkisinin değerlendirilmesidir. Gereç ve Yöntem: 60 adet çekilmiş üst santral diş Protaper Next rotary enstrüman ile X4 (40\#)'e kadar şekillendirildi. Numuneler rastgele eşit sayıda olacak şekilde, final irrigasyon yöntemine göre 4 gruba ayrıldı (n:15); Grup 1:\%2,5 sodyum hipoklorit (NaOCl) (kontrol), Grup2: \%17 EDTA, Grup3: \%2 klorheksidin (CHX), Grup4: QMix 2 in 1. Irrigasyondan sonra dişler Endosequence BC kanal patı ile güta-perka kullanılarak dolduruldu. Kök kanalının apikal, orta ve koronal üçte birlik kısımlarından kesitler alındı. Push-out testi ile kanal patı ve kök kanal dentini arasındaki bağlanma dayanımı ölçüldü. Datalar istatistiksel olarak analiz edildi. Sonuç: Kök kanal patının dentine bağlanmasını irrigasyon solüsyonunun tipi önemli ölçüde etkilemiştir. Qmix solüsyonu ile en yüksek bağlanma dayanımı oluşurken bu sonuçlar kök kanalının anatomik bölümlerine bakılmaksızın elde edilmiştir. Anahtar kelimeler: Endosequence BC kanal patı; irrigan; push-out test; Qmix; endodonti

\section{References}

1. Hulsmann M, Stryga F. Comparison of root canal preparation using different automated devices and hand instrumentation. J Endod 1993; 19: 141-5. [CrossRef]

2. Peters OA, Laib A, Gohring TN, Barbakow F. Changes in root canal geometry after preparation assessed by high-resolution computed tomography. J Endod 2001; 27: 1-6. [CrossRef]

3. Peters OA, Peters $\mathrm{Cl}$, Schonenberger K, Barbakow F. Protaper rotary root canal preparation: Assessment of torque and force in relation to canal anatomy. Int Endod J 2003; 36: 93-9. [CrossRef]

4. Rodig T, Hulsmann M, Muhge M, Schafers F. Quality of preparation of oval distal root canals in mandibular molars using nickel-titanium instruments. Int Endod J 2002; 35: 919-28. [CrossRef]

5. Wu MK, Wesselink PR. A primary observation on the preparation and obturation of oval canals. Int Endod J 2001; 34: 137-41. [CrossRef]

6. Naenni N, Thoma K, Zehnder M. Soft tissue dissolution capacity of currently used and potential endodontic irrigants. J Endod 2004; 30: 785-7. [CrossRef]

7. Violich DR, Chandler NP. The smear layer in endodontics - a review. Int Endod J 2010; 43: 2-15. [CrossRef]

8. Marending M, Paque F, Fischer J, Zehnder M. Impact of irrigant sequence on mechanical properties of human root dentin. J Endod 2007; 33: 1325-8. [CrossRef]

9. Zehnder $\mathrm{M}$, Schmidlin $\mathrm{P}$, Sener B, Waltimo T. Chelation in root canal therapy reconsidered. J Endod 2005;31(11):817-820. [CrossRef]

10. Baumgartner JC, Mader CL. A scanning electron microscopic evaluation of four root canal irrigation regimens. J Endod 1987; 13: 147-57. [CrossRef]

11. Ma J, Wang Z, Shen Y, Haapasalo M. A new noninvasive model to study the effectiveness of dentin disinfection by using confocal laser scanning microscopy. J Endod 2011; 37: 1380-5. [CrossRef]

12. Elnaghy AM. Effect of qmix irrigant on bond strength of glass fibre posts to root dentine. Int Endod J 2014; 47: 280-9. [CrossRef]

13. Eliot $C$, Hatton JF, Stewart GP, Hildebolt CF, Jane Gillespie M, Gutmann JL. The effect of the irrigant qmix on removal of canal wall smear layer: An ex vivo study. Odontology 2014; 102: 232-40. [CrossRef]

14. Bui TB, Baumgartner JC, Mitchell JC. Evaluation of the interaction between sodium hypochlorite and chlorhexidine gluconate and its effect on root dentin. J Endod 2008; 34: 181-5. [CrossRef]

15. Singh G, Gupta I, Elshamy FM, Boreak N, Homeida HE. In vitro comparison of antibacterial properties of bioceramic-based 
sealer, resin-based sealer and zinc oxide eugenol based sealer and two mineral trioxide aggregates. Eur J Dent 2016; 10: 366-9. [CrossRef]

16. Kokkas AB, Boutsioukis A, Vassiliadis LP, Stavrianos CK. The influence of the smear layer on dentinal tubule penetration depth by three different root canal sealers: An in vitro study. J Endod 2004; 30: 100-2. [CrossRef]

17. Ballal NV, Moorkoth S, Mala K, Bhat KS, Hussen SS, Pathak S. Evaluation of chemical interactions of maleic acid with sodium hypochlorite and chlorhexidine gluconate. J Endod 2011; 37: 1402-5. [CrossRef]

18. Kara Tuncer $A$. Effect of qmix $2 \mathrm{in} 1$ on sealer penetration into the dentinal tubules. J Endod 2015; 41: 257-60. [CrossRef]

19. Razmi H, Bolhari B, Karamzadeh Dashti N, Fazlyab M. The effect of canal dryness on bond strength of bioceramic and epoxy-resin sealers after irrigation with sodium hypochlorite or chlorhexidine. Iran Endod J 2016; 11: 129-33.

20. Attal JP, Asmussen E, Degrange M. Effects of surface treatment on the free surface energy of dentin. Dent Mater 1994; 10: 25964. [CrossRef]

21. Dogan Buzoglu H, Calt S, Gumusderelioglu M. Evaluation of the surface free energy on root canal dentine walls treated with chelating agents and naocl. Int Endod J 2007; 40: 18-24. [CrossRef]

22. Erickson RL. Surface interactions of dentin adhesive materials. Oper Dent 1992; Suppl 5: 81-94.

23. Hu X, Ling J, Gao Y. Effects of irrigation solutions on dentin wettability and roughness. J Endod 2010; 36: 1064-7. [CrossRef]

24. Ballal NV, Tweeny A, Khechen K, Prabhu KN, Satyanarayan, Tay FR. Wettability of root canal sealers on intraradicular dentine treated with different irrigating solutions. J Dent 2013; 41: 55660. [CrossRef]

25. Kuruvilla JR, Kamath MP. Antimicrobial activity of $2.5 \%$ sodium hypochlorite and $0.2 \%$ chlorhexidine gluconate separately and combined, as endodontic irrigants. J Endod 1998; 24: 472-6. [CrossRef]

26. Akisue E, Tomita VS, Gavini G, Poli de Figueiredo JA. Effect of the combination of sodium hypochlorite and chlorhexidine on dentinal permeability and scanning electron microscopy precipitate observation. J Endod 2010; 36: 847-50. [CrossRef]

27. Aranda-Garcia AJ, Kuga MC, Vitorino KR, Chavez-Andrade GM, Duarte MA, Bonetti-Filho I, Faria G, So MV. Effect of the root canal final rinse protocols on the debris and smear layer removal and on the push-out strength of an epoxy-based sealer. Microsc Res Tech 2013; 76: 533-7. [CrossRef]

28. Dai L, Khechen K, Khan S, Gillen B, Loushine BA, Wimmer CE, Gutmann JL, Pashley D, Tay FR. The effect of qmix, an experimental antibacterial root canal irrigant, on removal of canal wall smear layer and debris. J Endod 2011; 37: 80-4. [CrossRef]

29. Stojicic S, Shen Y, Qian W, Johnson B, Haapasalo M. Antibacterial and smear layer removal ability of a novel irrigant, qmix. Int Endod J 2012; 45: 363-71. [CrossRef]

30. Shokouhinejad N, Hoseini A, Gorjestani H, Shamshiri AR. The effect of different irrigation protocols for smear layer removal on bond strength of a new bioceramic sealer. Iran Endod J 2013; 8: 10-3.

31. Dogan H, Qalt S. Effects of chelating agents and sodium hypochlorite on mineral content of root dentin. J Endod 2001; 27: 578-80. [CrossRef]

32. Uzunoglu E, Turker SA, Karahan S. The effect of increased temperatures of qmix and edta on the push-out bond strength of an epoxy-resin based sealer. J Clin Diagn Res 2015; 9: 98-101. [CrossRef]

33. Carvalho NK, Prado MC, Senna PM, Neves AA, Souza EM, Fidel SR, Sassone LM, Silva EJ. Do smear-layer removal agents affect the push-out bond strength of calcium-silicate based endodontic sealers? Int Endod J 2017; 50: 612-9. [CrossRef] 